\title{
Fusarium oxysporum f. sp. cubense Consists of a Small Number of Divergent and Globally Distributed Clonal Lineages
}

\author{
R. L. Koenig, R. C. Ploetz, and H. C. Kistler
}

First and third author: Department of Plant Pathology, University of Florida, Gainesville 32611-0680; and second author: University of Florida, Tropical Research and Education Center, Homestead 33031-3314. Accepted for publication 31 May 1997.

\begin{abstract}
Koenig, R. L., Ploetz, R. C., and Kistler, H. C. 1997. Fusarium oxysporum $\mathrm{f}$. sp. cubense consists of a small number of divergent and globally distributed clonal lineages. Phytopathology 87:915-923.

A worldwide collection of Fusarium oxysporum f. sp. cubense was analyzed using anonymous, single-copy, restriction fragment length polymorphism (RFLP) loci. Several lines of evidence indicated that this pathogen has a clonal population structure. Of the 165 isolates examined, only 72 RFLP haplotypes were identified, and nearly half the isolates were represented by the five most common haplotypes. Individuals with identical haplotypes were geographically dispersed, and clone-corrected tests of gametic disequilibrium indicated significant nonrandom association among pairs of alleles for 34 of 36 loci tested. Parsimony analysis di-

vided haplotypes into two major branches (bootstrap value $=99 \%$ ) that together contained eight clades supported by significant bootstrap values. With the exception of two isolates, all isolates within a vegetative compatibility group were in the same clade and clonal lineage. Clonal lineages were defined by isolates having coefficients of similarity between 0.94 and 1.00. Ten clonal lineages were identified, and the two largest lineages had pantropical distribution. Minor lineages were found only in limited geographical regions. Isolates composing one lineage (FOC VII) may represent either an ancient genetic exchange between individuals in the two largest lineages or an ancestral group. The two largest lineages (FOC I and FOC II) and a lineage from East Africa (FOC V) are genetically distinct; each may have acquired the ability to be pathogenic on banana independently.
\end{abstract}

Fusarium wilt of banana, commonly referred to as Panama disease, is caused by Fusarium oxysporum Schlechtend.: Fr. f. sp. cubense (E.F. Sm.) W.C. Snyder \& H.N. Hans. Isolates of F. oxysporum f. sp. cubense previously have been characterized by morphology or biochemical and genetic markers. On morphological bases, F. oxysporum was included in section Elegans by Wollenweber and Reinking (37). No teleomorph has been described for the species.

Vegetative compatibility groups (VCGs) have been used to group isolates of $F$. oxysporum including $F$. oxysporum $\mathrm{f}$. sp. cubense. Based on data from other fungi, isolates that share identical alleles at the loci governing heterokaryon incompatibility, commonly referred to as het or vic, are vegetatively compatible (14). Conventionally, this is determined by the ability of nitrate-nonutilizing auxotrophic mutants (nit) to complement one another for nitrate utilization (6). Currently, at least 21 VCGs have been described for this forma specialis $(22,23,26)$. The majority of isolates belong to two major VCGs that have a pantropical distribution, and each contains more than one race of the pathogen. Minor VCGs were found to have a more limited geographical distribution $(22,23)$. For an asexually reproducing organism like $F$. oxysporum, it is generally assumed that isolates within a VCG are genetically similar and represent clonal populations $(1,10,33)$.

In addition to characterizing isolates by VCG, isolates of $F$. $o x$ ysporum f. sp. cubense have been grouped based on electrophoretic karyotype, randomly amplified polymorphic DNA (RAPD) analysis, and the ability to produce volatile organic compounds in culture. Boehm et al. (3) proposed two groupings of isolates of $F$. oxysporum $\mathrm{f}$. sp. cubense based on similarities in chromosome number and genome size. Group I was composed of isolates in VCGs 0124, 0125, 0124/0125, 01210, and 01214. Group II was com-

Corresponding author: H. C. Kistler; E-mail address: hck@gnv.ifas.ufl.edu

Publication no. P-1997-0722-01R

(c) 1997 The American Phytopathological Society posed of isolates in VCGs 0120, 0121, 0122, 0123, 0129, and 01213. In general, these groupings agreed with RAPD data $(2,30)$. When the presence or absence of RAPD bands was treated as binary data and subjected to phenetic analysis based on the unweighted pair group method with arithmetic mean (UPGMA), isolates in VCGs 0120, 0121, 0122, 0126, 01210, 01211, and 01212 formed one group, and isolates in VCGs 0123, 0124, 0124/0125, and 0125 formed a second group.

Similar major groups of isolates were evident when differentiation was based on the formation of aldehydes in culture. Brandes (5) noted that certain isolates of the pathogen produced these odorous compounds when grown on steamed rice, whereas others did not; the latter isolates were classified as variety inodoratum. Stover (31) examined a larger set of isolates from tropical America and the Caribbean and noted that production of odorous compounds was a consistent and repeatable trait. Those isolates that produced the aldehydes were referred to as cultivar Odoratum, whereas those that did not were referred to as cultivar Inodoratum. More recently, Moore et al. $(19,20)$ analyzed the production of these compounds with high pressure liquid chromatography. Isolates in VCGs 0120,0129 , and 01211 produced characteristic volatile profiles, whereas isolates in VCGs 0123, 0124, 0124/0125, 0125, and 0128 did not.

Restriction fragment length polymorphisms (RFLPs) also have been employed to determine the genetic relationships among isolates of $F$. oxysporum. These markers are ideally suited to genetic diversity studies because of the following characteristics: (i) most are selectively neutral, (ii) polymorphisms tend to be more numerous compared with other types of markers such as isozymes, (iii) they are reproducible, and (iv) those identifying random single-copy loci avoid problems that are associated with the physical linkage of genetic markers.

In this study, probes from $F$. oxysporum f. sp. lycopersici that correspond to single-copy, anonymous loci (8) were used to identify polymorphic alleles in $F$. oxysporum f. sp. cubense. Our objectives were to determine whether isolates within VCGs of $F$. ox- 
ysporum f. sp. cubense were clonally derived and if clonal lineages correlated with previously determined VCGs. We also wished to characterize the phylogenetic relationships among isolates of $F$. oxysporum $\mathrm{f}$. sp. cubense representing the various VCGs and isolates of $F$. oxysporum from other hosts to determine if host specificity was derived from a common ancestor.

\section{MATERIALS AND METHODS}

Fungal isolates. One hundred sixty-five isolates representing the worldwide distribution and 17 VCGs of $F$. oxysporum $\mathrm{f}$. sp. cubense were selected for analysis from the collection located at the University of Florida, Tropical Research and Education Center in Homestead, FL (Table 1). All isolates were recovered from symptomatic vascular tissues of the indicated banana cultivars (Table 1). Furthermore, one to several representative isolates within each of the examined VCGs were pathogenic on at least one, and as many as eight, different banana cultivars (R. C. Ploetz, unpublished data). For these reasons, all isolates used in this study were considered $F$. oxysporum f. sp. cubense. In addition to $F$. oxysporum f. sp. cubense isolates, three isolates of $F$. oxysporum f. sp. lycopersici and a single isolate of $F$. oxysporum $\mathrm{f}$. sp. niveum were analyzed to compare results with genotypes representing different formae speciales.
DNA isolation. All cultures were derived from single microconidia and were stored at $4^{\circ} \mathrm{C}$ on strips of Whatman filter paper (Whatman International, Ltd., Maidstone, England) (6). Paper strips were plated onto potato dextrose agar (PDA) (Difco Laboratories, Detroit). After approximately 7 days of growth at $27^{\circ} \mathrm{C}$, a $5-\mathrm{mm}^{3}$ block was excised from the margin of colonies on PDA and transferred to 4-liter Erlenmeyer flasks containing at least 100 $\mathrm{ml}$ of potato dextrose broth ( $24 \mathrm{~g} /$ liter; Difco Laboratories). After 7 to 10 days of growth in still culture, the contents of the flask were filtered through sterilized cheesecloth to collect mycelium. The mycelium was placed into $13-\mathrm{ml}$ plastic tubes, frozen at $-80^{\circ} \mathrm{C}$, and lyophilized for at least $12 \mathrm{~h}$.

Buffer for DNA extraction was composed of a 1:1:0.4 volume of the following solutions: buffer A $(0.3 \mathrm{M}$ sorbitol, $0.1 \mathrm{M}$ Tris, and $20 \mathrm{mM}$ EDTA, $\mathrm{pH} 7.5)$, buffer B (0.2 M Tris, $\mathrm{pH} 7.5 ; 50 \mathrm{mM}$ EDTA; and $0.2 \mathrm{mM}$ cetyltrimethylammonium bromide), and $5 \%$ Sarkosyl. Ten milliliters of the extraction buffer was mixed with approximately $0.5 \mathrm{~g}$ of ground mycelial powder, and the tubes were placed in a $65^{\circ} \mathrm{C}$ water bath for $30 \mathrm{~min}$. The contents of the tubes were then shaken, and $1 \mathrm{ml}$ of solution was transferred to each of 10 sterile $1.5-\mathrm{ml}$ microcentrifuge tubes. Five hundred microliters of chloroform/octanol $(24: 1)$ solution was added to each tube. The solution was mixed using a vortex shaker for approximately 2 min before centrifugation for $10 \mathrm{~min}$ at $12,000 \times g$ in a microcentrifuge

TABLE 1 . List of isolates analyzed in this study

\begin{tabular}{|c|c|c|c|c|c|c|c|c|c|}
\hline $\mathrm{VCG}^{\mathrm{u}}$ & Isolate & Cultivar $^{\mathrm{v}}$ & Origin and collector $^{\mathrm{W}}$ & $\begin{array}{c}\text { FOC } \\
\text { lineage }\end{array}$ & $\mathrm{VCG}^{\mathrm{u}}$ & Isolate & Cultivar $^{\mathrm{v}}$ & Origin and collector $^{\mathrm{W}}$ & $\begin{array}{c}\text { FOC } \\
\text { lineage }\end{array}$ \\
\hline \multirow[t]{30}{*}{0120} & IC2 & Cavendish & Icod de los Vinos, Canary Islands, d & II & 0122 & $\mathrm{Ph} 3$ & Cavendish & Philippines, 1 & VI \\
\hline & 22425 & Cavendish & Wamuran, Queensland, Australia, g & II & & $\mathrm{Ph} 6$ & Cavendish & Philippines, 1 & VI \\
\hline & ORT2 & Cavendish & La Orotava, Canary Islands, $\mathrm{d}$ & II & & P79 & Cavendish & Philippines, h & VI \\
\hline & $0-1220$ & Mons Mari & Queensland, Australia, c & II & & LAP & Cavendish & Philippines, $\mathrm{h}$ & VI \\
\hline & GAL2 & Cavendish & Las Galletas, Canary Islands, $\mathrm{d}$ & II & & SABA & Saba & Philippines, $\mathrm{h}$ & VI \\
\hline & $\mathrm{C} 2$ & Cavendish & Canary Islands, $\mathrm{f}$ & II & & PW3 & Cavendish & Philippines, $\mathrm{m}$ & VI \\
\hline & ADJ2 & Cavendish & Adeje, Canary Islands, $\mathrm{d}$ & II & & PW6 & Cavendish & Philippines, $\mathrm{m}$ & VI \\
\hline & $\mathrm{C} 1$ & Cavendish & Canary Islands, $\mathrm{f}$ & II & & PW7 & Cavendish & Philippines, $\mathrm{m}$ & VI \\
\hline & 22424 & Lady Finger & Moorina, Queensland, Australia, g & II & 0123 & DAVAO & Silk & Philippines, h & VII \\
\hline & $0-1222$ & Mons & Queensland, Australia, c & II & & $\mathrm{T} 1$ & Gros Michel & Taiwan, $\mathrm{f}$ & VII \\
\hline & $0-1219$ & Mons & Queensland, Australia, c & II & & $\mathrm{PhL} 2$ & Latundan & Philippines, i & VII \\
\hline & A2 & Mons Mari & Australia, $\mathrm{f}$ & II & & Ph12 & Latundan & Philippines, 1 & VII \\
\hline & ADJ1 & Cavendish & Adeje, Canary Islands, $\mathrm{d}$ & II & & F9129 & Latundan & Taiwan, g & VII \\
\hline & STGM1 & Gros Michel & Costa Rica, i & II & & JLTH4 & Kluai namwa & Smoeng Hwy 1269, Thailand, v & $\mathrm{X}$ \\
\hline & $3 \mathrm{~S} 1$ & Highgate & Honduras, i & II $^{\mathrm{X}}$ & & JLTH5 & Kluai namwa & Smoeng Hwy 1269 , Thailand, v & $\mathrm{X}^{\mathrm{x}}$ \\
\hline & PAJ1 & Cavendish & Pajalillos, Canary Islands, d & II & 0124 & A36 & $?$ & Brazil, $\mathrm{k}$ & I \\
\hline & ORT1 & Cavendish & La Orotava, Canary Islands, d & II & & GMB & Gros Michel & Brazil, n & I \\
\hline & GAL1 & Cavendish & Las Galletas, Canary Islands, $\mathrm{d}$ & II & & Maça & Maça & Brazil, n & I \\
\hline & BUE1 & Cavendish & Buenavista, Canary Islands, d & II & & STPA1 & Pisang Awak & Burundi, i & I \\
\hline & NW & Williams & Natal, South Africa, $f$ & II & & STD2 & Highgate & Honduras, i & I \\
\hline & NH & Williams & Natal, South Africa, $f$ & II & & BLUG & Bluggoe & Honduras, $\mathrm{h}$ & I \\
\hline & NB & Cavendish & Natal, South Africa, $f$ & II & & S? & Tetraploid 1242 & Bodles, Jamaica, i & I \\
\hline & F9127 & Grand Naine & South Africa, $g$ & II & & FCJ2 & Bluggoe & Jamaica, q & I \\
\hline & 15638 & $?$ & Malaysia, a & II & & FCJ3 & $?$ & Jamaica, q & I \\
\hline & FCJ7 & Lacatan & Jamaica, q & II & & FCJ8 & $?$ & Jamaica, q & I \\
\hline & Pacovan & Pacovan & Bahia, Brazil, n & II & & FCJ9 & Tetraploid 1242 & Jamaica, q & I \\
\hline & MGSA1 & SH3142 & South Africa, s & II & & STJ2 & Grande Naine & Jamaica, i & I \\
\hline & SA6 & Cavendish & Transvaal, South Africa, b & II & & MW43 & Harare & Chitipa, Karonga, Malawi, b & I \\
\hline & SA4 & SH3362 & Natal, South Africa, b & $\mathrm{II}^{\mathrm{X}}$ & & MW45 & Harare & Chitipa, Karonga, Malawi, b & I \\
\hline & SA3 & Williams & Transvaal, South Africa, b & II & & MW47 & Harare & Chesenga, Malawi, b & $\mathrm{I}^{\mathrm{X}}$ \\
\hline \multirow[t]{7}{*}{0121} & GM & Gros Michel & Taiwan, $\mathrm{h}$ & & & MW50 & Harare & Chitipa, Karonga, Malawi, b & I \\
\hline & 9130 & Cavendish & Taiwan, g & III & & MW52 & Sukali & Karonga South, Malawi, b & I \\
\hline & $0-1124$ & $?$ & Taiwan, c & $\mathrm{III}^{\mathrm{x}}$ & & MW58 & Harare & Karonga, Malawi, b & I \\
\hline & $\mathrm{H} 1$ & Cavendish & Taiwan, e & III & & MW64 & Harare & Kaporo North, Malawi, b & I \\
\hline & ML & Cavendish & Taiwan, h & III & & MW67 & Kholobowa & Thyolo, Blantyre, Malawi, b & I \\
\hline & TBR & Cavendish & Taiwan, h & III & & MW69 & Kholobowa & Thyolo, Blantyre, Malawi, b & I \\
\hline & & & & & & & & (continu & t page \\
\hline
\end{tabular}

u Vegetative compatibility groups (VCGs) were assigned using nitrogen metabolism mutants (nit) according to the protocols of Cove (1976) as modified by Puhalla and Correll (1985).

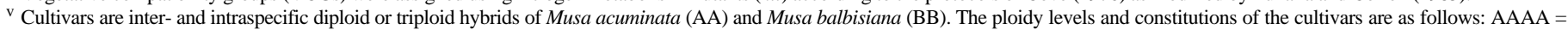
Tetraploid 1242; AAA = Gros Michel, Highgate, Mons (Mons Mari), Cavendish, Dwarf Cavendish, Grande Naine, Williams, and Lacatan; AA = SH3142 and SH3362 (synthetic clones); AAB = Apple, Lady Finger, Pacovan, Prata, Silk, Latundan, Maqueño, and Maça; ABB = Saba, Bluggoe, Harare, Kholobowa, Pisang Awak, Kluai namwa, Ducasse, Mbufu, Burro, and Zambia; and $\mathrm{AB}=$ Ney Poovan and Sukali.

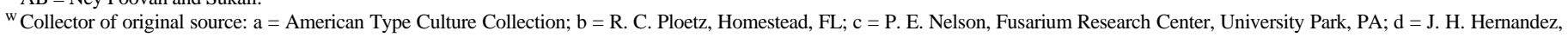
Tenerife, Canary Islands; e = S. C. Hwang, Taiwan Banana Research Institute, Pingtung; f = B. Manicom, Nelspruit, South Africa; g = K. Pegg, Brisbane, Australia; h = S. Nash Smith, Alameda, CA; i = R. H. Stover, La Lima, Honduras; j = IFRA, Montpellier, France (via R. C. Stover); l = A. M. Pedrosa, Philippines; $\mathrm{m}=$ N. I. Roperos, Philippines; $\mathrm{n}=$ Z. J. M. Cordeiro, EMBRAPA, Cruz das Almas, Brazil (via E. D. Loudres); q = J. Ferguson-Conie, Banana Board, Kingston, Jamaica; $r=$ B. Braunworth, Oregon State University, Corvallis; u = T.-Y. Chuang, National Taiwan University, Taipei; $v$ = J. Leslie, Kansas State University, Manhattan; and w = F. Martin, USDA, ARS, Salinas, CA.

${ }^{x}$ Missing data made it impossible to determine coefficient of similarity but, based on all other data, it is presumed to be in the lineage indicated.

${ }^{y}$ Unique isolate that had no lineage affinity based on defined criteria; the lineage assigned is based on coefficients of similarity to the most closely related isolates.

$\mathrm{z}$ Isolates analyzed with this designation do not correspond to any isolates currently held in the Homestead collection. 
at room temperature. Unless noted, all further centrifuge steps were done in a microcentrifuge at room temperature. The supernatant was transferred to sterile $1.5-\mathrm{ml}$ tubes and treated with $5 \mu \mathrm{l}$ of $20 \mathrm{mg}$ of RNase A (Sigma Chemical Co., St. Louis)/ml of solution for 30 $\min$ at $37^{\circ} \mathrm{C}$. Following RNase treatment, $5 \mu \mathrm{lof} 20 \mathrm{mg}$ of proteinase K (Sigma Chemical Co.)/ml of solution was added to the tubes, and the tubes were incubated for $20 \mathrm{~min}$ at $37^{\circ} \mathrm{C}$. Approximately one volume of isopropanol was added, and the tubes were centrifuged for $15 \mathrm{~min}$ at $12,000 \times \mathrm{g}$. The isopropanol then was discarded, and $100 \mu \mathrm{l}$ of ice-cold $70 \%$ ethanol was added before centrifugation for $5 \mathrm{~min}$. The ethanol was discarded, and the DNA sample was air-dried for at least $30 \mathrm{~min}$ in a laminar flow hood. At least $100 \mu \mathrm{l}$ of TE buffer (10 mM Tris and $1 \mathrm{mM}$ EDTA, pH 7.4) was added to the tubes, and the tubes were placed in a water bath at $65^{\circ} \mathrm{C}$ until the DNA pellet was dissolved.

Samples that were difficult to bring into solution were subjected to a $\mathrm{LiCl}$ treatment. Three hundred microliters of ice-cold $4 \mathrm{M}$ $\mathrm{LiCl}$ solution was added to each tube, and the tubes were placed on ice for $30 \mathrm{~min}$ before centrifugation at $12,000 \times \mathrm{g}$ for $10 \mathrm{~min}$ at $4^{\circ} \mathrm{C}$. The supernatant was transferred to a sterile $1.5-\mathrm{ml}$ tube containing $600 \mu \mathrm{l}$ of isopropanol. This solution was mixed, and the tubes were kept at room temperature for $30 \mathrm{~min}$. After centrifugation at $12,000 \times g$ for $10 \mathrm{~min}$ at $4^{\circ} \mathrm{C}$, the supernatant was discarded, and $100 \mu \mathrm{l}$ of ice-cold $70 \%$ ethanol was added to the tubes. After centrifugation at $12,000 \times g$ for $5 \mathrm{~min}$, the ethanol was discarded, and the DNA was air-dried. TE buffer $(100 \mu \mathrm{l})$ was added to the tubes, and the tubes were placed in a water bath at $65^{\circ} \mathrm{C}$ until the DNA pellet was dissolved.

The concentration of DNA in the samples was estimated by running $3 \mu \mathrm{l}$ of each sample on an agarose gel along with DNA fragments (bacteriophage lambda DNA digested with $P s t \mathrm{I}$ ) of a known concentration and making visual comparisons of their relative fluorescence in the presence of UV light and $0.5 \mu \mathrm{g}$ of ethidium bromide/ml of solution.

Southern blotting and hybridization. Approximately $10 \mu \mathrm{g}$ of DNA was digested with at least 10 units of either DraI, EcoRV, or HaeIII restriction enzymes (Bethesda Research Laboratories, Gaithersburg, MD) and incubated for at least $3 \mathrm{~h}$. These restriction enzymes were chosen based on their insensitivity to DNA methylation and their ability to digest DNA consistently. Restriction fragments were separated by electrophoresis in $0.7 \%$ agarose for EcoRV- and DraI-digested DNA or $1.5 \%$ agarose for HaeIII-digested DNA in Tris-borate-EDTA (TBE) buffer at $\mathrm{pH}$ 7.0. Gels were run at either $30 \mathrm{~V}$ for approximately $16 \mathrm{~h}$ or $40 \mathrm{~V}$ for approximately $12 \mathrm{~h}$. Bacteriophage lambda DNA digested with either PstI or HindIII was included on each gel and used to calculate the molecular mass of restriction fragments obtained from $F$. oxysporum f. sp. cubense DNA. Ethidium bromide $(10 \mathrm{mg} / \mathrm{ml})$ was

TABLE 1. (continued from the preceding page)

\begin{tabular}{|c|c|c|c|c|c|c|c|c|c|}
\hline $\mathrm{VCG}^{\mathrm{u}}$ & Isolate & Cultivar $^{\mathrm{V}}$ & Origin and collector $^{\mathrm{W}}$ & $\begin{array}{c}\text { FOC } \\
\text { lineage }\end{array}$ & $\mathrm{VCG}^{\mathrm{u}}$ & Isolate & Cultivar $^{\mathrm{V}}$ & Origin and collector $^{\mathrm{W}}$ & $\begin{array}{c}\text { FOC } \\
\text { lineage }\end{array}$ \\
\hline & MW71 & Kholobowa & Mulanje, Blantyre, Malawi, b & I & & N5443 & Cavendish & Doonan, Queensland, Australia, g & II \\
\hline & MW78 & Harare & Vinthukutu, Karonga, Malawi, b & I & & 8627 & Cavendish & North Arm, Queensland, Australia, g & II \\
\hline & STN2 & Bluggoe & Corinto, Nicaragua, i & I & & 22402 & Cavendish & Wamuran, Queensland, Australia, g & II \\
\hline & STN5 & Bluggoe & Corinto, Nicaragua, i & I & & 8604 & Cavendish & North Arm, Queensland, Australia, g & II \\
\hline & STN6 & Bluggoe & Corinto, Nicaragua, i & I & 01210 & A2-1 & Apple & Florida, United States, b & IV \\
\hline & STN7 & Bluggoe & Corinto, Nicaragua, i & I & & A4-1 & Apple & Florida, United States, b & IV \\
\hline & STPA2 & Pisang Awak & Tanzania, i & I & & CSB & Apple & Florida, United States, b & IV \\
\hline & B1 & Burro (Bluggoe) & Florida, United States, b & I & & $\mathrm{JC} 14$ & Apple & Florida, United States, b & IV \\
\hline & B2-1 & Burro & Florida, United States, b & I & & A15 & Apple & Florida, United States, b & $\mathrm{IV}^{\mathrm{y}}$ \\
\hline & JCB1 & Burro & Florida, United States, b & I & & A3-1 & Apple & Florida, United States, b & IV \\
\hline & JLTH2 & Kluai namwa & Smoeng Hwy 1269, Thailand, v & I & & JC8 & Apple & Florida, United States, b & IV \\
\hline & JLTH7 & Kluai namwa & Smoeng Hwy 1269, Thailand, v & I & & $\mathrm{F} 2$ & Apple & Florida, United States, b & IV \\
\hline & JLTH15 & Kluai namwa & Chai Yo Hwy, Thailand, v & I & & F3 & Apple & Florida, United States, b & IV \\
\hline \multirow{17}{*}{$\begin{array}{r}0124 / \\
0125\end{array}$} & & & & & & $\mathrm{JC} 1$ & Apple & Florida, United States, b & IV \\
\hline & MW9 & Zambia & Kaporo, Malawi, r & I & & GG1 & Apple & Florida, United States, b & IV \\
\hline & MW11 & Harare & Kaporo, Malawi, r & I & 01211 & 13721 & $?$ & $?, \mathrm{a}$ & $\mathrm{IX}^{\mathrm{x}}$ \\
\hline & MW39 & Harare & Chitipa, Karonga, Malawi, b & I & & SH3142 & SH3142 & Queensland, Australia, g & IX \\
\hline & MW53 & Sukali & Karonga, Malawi, b & $\mathrm{I}^{\mathrm{X}}$ & 01212 & STNP1 & Ney Poovan & Pemba Island, Zanzibar, Tanzania, i & VIII \\
\hline & MW56 & Zambia & Karonga, Malawi, b & I & & STNP2 & Ney Poovan & Tenguero Station, Tanzania, i & VIII \\
\hline & MW60 & Zambia & Karonga, Malawi, b & I & & STNP4 & Ney Poovan & Bukava Station, Tanzania, i & VIII \\
\hline & MW61 & Harare & Vinthukutu, Karonga, Malawi, b & I & 01213 & $1-1$ & Cavendish & Taiwan, u & III \\
\hline & MW63 & Harare & Karonga, South, Malawi, b & I & & $2-1$ & Cavendish & Taiwan, u & III \\
\hline & MW66 & Kholobowa & Thyolo, Blantyre, Malawi, b & I & & $6-2$ & Cavendish & Taiwan, u & III \\
\hline & MW70 & Kholobowa & Thyolo, Blantyre, Malawi, b & I & & $5-1-1$ & Cavendish & Taiwan, u & III \\
\hline & MW86 & Mbufu & Chitipa, Karonga, Malawi, b & I & & $4-2-1$ & Cavendish & Taiwan, u & III \\
\hline & JLTH1 & Kluai namwa & Ban Nok, Thailand, v & I & & $4-1-1$ & Cavendish & Taiwan, u & III \\
\hline & JLTH16 & Kluai namwa & Ban Nok, Thailand, v & I & & $2-2$ & Cavendish & Taiwan, u & III \\
\hline & JLTH17 & Kluai namwa & Ban Nok, Thailand, v & $\mathrm{I}^{\mathrm{X}}$ & & ES2-1 & Cavendish & Taiwan, u & \\
\hline & JLTH18 & Kluai namwa & Ban Nok, Thailand, v & $\mathrm{I}^{\mathrm{X}}$ & 01214 & MW2 & Harare & Misuku, Karonga, Malawi, r & V \\
\hline & JLTH19 & Kluai namwa & Ban Nok, Thailand, v & I & & MW40 & Harare & Misuku Hills, Karonga, Malawi, b & $\mathrm{V}$ \\
\hline \multirow[t]{12}{*}{0125} & A4 & Lady Finger & Australia, $\mathrm{f}$ & I & & MW41 & Mbufu & Misuku Hills, Karonga, Malawi, b & $\mathrm{V}$ \\
\hline & 8606 & Lady Finger & Currumbin, Queensland, g & I & & MW42 & Harare & Misuku Hills, Karonga, Malawi, b & $\mathrm{V}$ \\
\hline & 8611 & Lady Finger & Currumbin, Queensland, g & I & & MW44 & Harare & Misuku Hills, Karonga, Malawi, b & $\mathrm{V}$ \\
\hline & 22468 & Lady Finger & Tomewin, Queensland, g & I & & MW46 & Harare & Misuku Hills, Karonga, Malawi, b & V \\
\hline & 22479 & Ducasse & Bowen, Queensland, Australia, g & $\mathrm{I}^{\mathrm{y}}$ & & MW48 & Harare & Misuku Hills, Karonga, Malawi, b & $\mathrm{V}$ \\
\hline & 22600 & Lady Finger & Murwillumbah, New S. Wales, Australia, g & I & & MW51 & Harare & Misuku Hills, Karonga, Malawi, b & $\mathrm{V}$ \\
\hline & 22417 & Lady Finger & Rocksberg, Queensland, Australia, g & I & & MW89 & Harare & Misuku Hills, Karonga, Malawi, b & V \\
\hline & 22541 & Lady Finger & Murwillumbah, New S. Wales, Australia, g & I & 01215 & CR1 & Gros Michel & Isolona, Costa Rica, b & II \\
\hline & $0-1223$ & Mons & Queensland, Australia, c & I & & CR2 & Gros Michel & Hamburgo, Rio Reventazon, Costa Rica, b & II \\
\hline & $1 \mathrm{~S} ?$ & Williams & Bodles, Jamaica, i & I & & CR4 & Gros Michel & Hamburgo, Rio Reventazon, Costa Rica, b & II \\
\hline & STPA3 & Pisang Awak & Uganda, i & I & & CR5 & Gros Michel & Hamburgo, Rio Reventazon, Costa Rica, b & II \\
\hline & JLTH20 & Kluai namwa & Ban Nok, Thailand, v & I & $0120 /$ & & & & \\
\hline \multirow[t]{4}{*}{0126} & $\mathrm{~S} 1$ & Highgate & Honduras, i & II & 01215 & INDO20 & Musa spp. & Jatesari, East Java, Indonesia, g & III \\
\hline & STA2 & Highgate & Honduras, i & II & & $\mathrm{INDO}^{\mathrm{z}} \mathrm{z}^{\mathrm{Z}}$ & Musa spp. & Jatesari, East Java, Indonesia, g & III \\
\hline & STM3 & Maqueño & Honduras, i & II & & INDO1 $8^{\mathrm{z}}$ & Musa spp. & Jatesari, East Java, Indonesia, g & III \\
\hline & STB2 & Highgate & Honduras, i & II & Fusariun & oxysporum $\mathrm{f}$ & sp. lycopersici & & \\
\hline \multirow[t]{3}{*}{0128} & 22993 & Bluggoe & South Johnstone, Queensland, g & $\mathrm{I}$ & & SC548 & Homestead & Bradenton, Florida & \\
\hline & 22994 & Bluggoe & South Johnstone, Queensland, Australia, g & I & & SC626 & Oristano & Italy & \\
\hline & A47 & Bluggoe & Comores Islands, $\mathrm{j}$ & $\mathrm{I}^{\mathrm{X}}$ & & SC761 & Sunny & Bradenton, Florida & \\
\hline \multirow[t]{2}{*}{0129} & N5331 & Cavendish & Yandina, Queensland, Australia, g & II & \multicolumn{3}{|c|}{ Fusarium oxysporum f. sp. niveum } & & \\
\hline & $0-1221$ & Mons & Queensland, Australia, c & II & 0082 & CS85-4 & & Florida, w & \\
\hline
\end{tabular}


dissolved in the agarose gel at a concentration of $1 \mu \mathrm{l}$ to $100 \mathrm{ml}$, and the digested DNA was illuminated by UV irradiation and photographed. The DNA was transferred to Nytran membranes (Schleicher \& Schuell, Inc., Keene, NH) using the capillary transfer method (27). The DNA transfer proceeded for at least $12 \mathrm{~h}$, and the DNA was immobilized by UV cross-linking (UV 254-nm cross linker, model FB UVXL 1000; Fisher Scientific Co., Pittsburgh).

To reduce the incidence of repeatedly scoring similar regions of the genome or hypervariable regions, clones containing singlecopy DNA sequences, obtained from T. Katan (The Volcani Center, Bet Dagan, Israel), were utilized (Table 2) (8). Clones were considered to be single-copy based on the criteria defined by Elias et al. (8) as hybridizing to only a single DNA fragment in any of the isolates tested using at least one of three restriction enzymes.

DNA for each clone was labeled using random hexamer primers to incorporate fluorescein-12-dUTP following the procedures provided by the manufacturer (Dupont NEN Renaissance; E. I. du Pont de Nemours \& Co. Inc., Boston). DNA labeling, hybridization, and detection followed the procedures provided by the manufacturer (E. I. du Pont de Nemours \& Co. Inc.). Prehybridization, hybridization, and washing were performed at $65^{\circ} \mathrm{C}$ using a Hybaid hybridization oven (Dot Scientific Inc., Flint, MI). Membranes were placed between acetate sheets and exposed to X-ray film for at least $5 \mathrm{~h}$.

Mitochondrial DNA of $F$. oxysporum f. sp. cubense isolate 3S1 (VCG 0120) was isolated following the procedures of Kistler and Leong (13) and labeled as described above. The mitochondrial DNA profiles of a subset of isolates were obtained by digesting approximately $10 \mu \mathrm{g}$ of total DNA with at least 10 units of the restriction enzyme HaeIII and probing with the mitochondrial DNA of isolate 3S1. Restriction fragments were separated by electrophoresis in $1.5 \%$ agarose in TBE buffer at $\mathrm{pH}$ 7.0. Gels were run at $30 \mathrm{~V}$ for approximately $22 \mathrm{~h}$. Southern blotting and hybridization followed the procedures described above.

Data analyses. Initially, a subset of 38 geographically widespread isolates of $F$. oxysporum f. sp. cubense that represented all 17 VCGs was used to determine if a particular probe-enzyme combination was polymorphic. Only polymorphic loci were considered informative for phylogeny determinations. If polymorphisms were detected in the subset, then all 165 isolates were analyzed for that probe-enzyme combination. If all isolates within the subset were monomorphic, it was assumed that the entire collection was monomorphic for that probe-enzyme combination. The different restriction size fragments generated for each combination of probe and enzyme were considered to be alleles at a single RFLP locus, and their presence or absence was scored for each isolate. RFLP patterns for each combination of probe and enzyme were combined to assign an RFLP haplotype to each isolate.

The data were analyzed by a cladistic approach based on parsimony analysis using the computer program PAUP version 3.1.1 (32) and by a phenetic approach using distance matrix methods (UPGMA clustering) (29) and the neighbor-joining algorithm of

TABLE 2. Clone and restriction enzyme combinations tested in study

\begin{tabular}{lccc}
\hline Clone & DraI & EcoRV & HaeIII \\
\hline FG7 & $\mathrm{P}^{\mathrm{x}}$ & $\mathrm{M}^{\mathrm{y}}$ & $\mathrm{P}$ \\
FG30 & $\mathrm{M}$ & $\mathrm{M}$ & $\mathrm{M}$ \\
FG120 & $\ldots \mathrm{z}^{\mathrm{z}}$ & $\ldots$ & $\mathrm{P}$ \\
FG162 & $\mathrm{P}$ & $\mathrm{M}$ & $\mathrm{P}$ \\
FG177 & $\ldots$ & $\mathrm{P}$ & $\ldots$ \\
FG187 & $\ldots$ & $\mathrm{P}$ & $\ldots$ \\
FG204 & $\ldots$ & $\mathrm{P}$ & $\mathrm{P}$ \\
FG225 & $\ldots$ & $\mathrm{P}$ & $\ldots$ \\
FG228 & $\ldots$ & $\mathrm{P}$ & $\ldots$ \\
FG260 & $\mathrm{P}$ & $\mathrm{P}$ & $\ldots$ \\
FG261 & $\ldots$ & $\mathrm{P}$ & $\ldots$
\end{tabular}

x $\mathrm{P}$ indicates polymorphic loci.

y $\mathrm{M}$ indicates monomorphic loci.

$\mathrm{z}$... indicates not tested.
Phylip version 3.5c (J. Felsenstein, University of Washington, Seattle). For parsimony analysis, phylogenies were derived by using the heuristic search option, and the degree of support was evaluated using 500 bootstrap replicates. In addition, coefficients of similarity based on simple matching (Ssm) were calculated for those isolates in which data were available for every RFLP loci scored, based on the formula described by Sneath and Sokal (29):

$$
\mathrm{Ssm}=m /(m+u)
$$

in which $m=$ the number of shared characters and $u=$ the number of unique characters. Isolates were arbitrarily considered to be within the same clonal lineage based on coefficients of similarity ranging from 0.94 to 1.00 . Since many of the isolates had identical multilocus haplotypes, only a single isolate was used to represent each haplotype in data analyses.

To determine whether this collection of isolates provided evidence for clonal reproduction, gametic disequilibrium between loci was calculated by methods described by Weir (35). The gametic disequilibrium coefficient $(D)$ for alleles $\mathrm{u}$ and $\mathrm{v}$ at different loci was used to compare the observed gametic frequency with the product of the gene frequencies such that

$$
D_{\mathrm{uv}}=p_{\mathrm{uv}}-p_{\mathrm{u}} p_{\mathrm{v}}
$$

in which $p_{\mathrm{uv}}$ was the observed gametic frequency and $p_{\mathrm{u}}$ and $p_{\mathrm{v}}$ were the observed frequencies of alleles $u$ and $v$ for any two loci. Clone-corrected allele frequencies, using only a single representative for each haplotype, were employed for the calculations. Also, to avoid the potential problem of repeatedly scoring similar regions, only data from a single restriction enzyme digestion were used for each probe in the analyses. Nine hundred eighty-eight pairwise comparisons were performed to test for disequilibrium between multiple alleles at nine loci. A test for the significance of the disequilibrium coefficient between each pair of alleles at two loci was formulated with the chi-square statistic

$$
\chi_{\mathrm{uv}}^{2}=\frac{n \hat{D}_{\mathrm{uv}}^{2}}{\widetilde{p}_{\mathrm{u}}\left(1-\widetilde{p}_{\mathrm{u}}\right) \widetilde{p}_{\mathrm{v}}\left(1-\widetilde{p}_{\mathrm{v}}\right)}
$$

in which $n$ was the number of individuals in the sample and $\hat{D}_{\mathrm{uv}}$ was the maximum likelihood estimator for the coefficient of disequilibrium between alleles $\mathrm{u}$ and $\mathrm{v}$.

The observed allele frequencies for the loci were $\tilde{p}_{u}$ and $\tilde{p}_{v}$, respectively $(17,35)$. The chi-square statistic had one degree of freedom, and the pairs of loci that showed significant departure from random expectations $(P<0.05)$ were considered to be in disequilibrium. A test for significance of the disequilibrium coefficient across all alleles for each pair of loci was formulated with the chisquare test statistic as described by McDonald et al. (17).

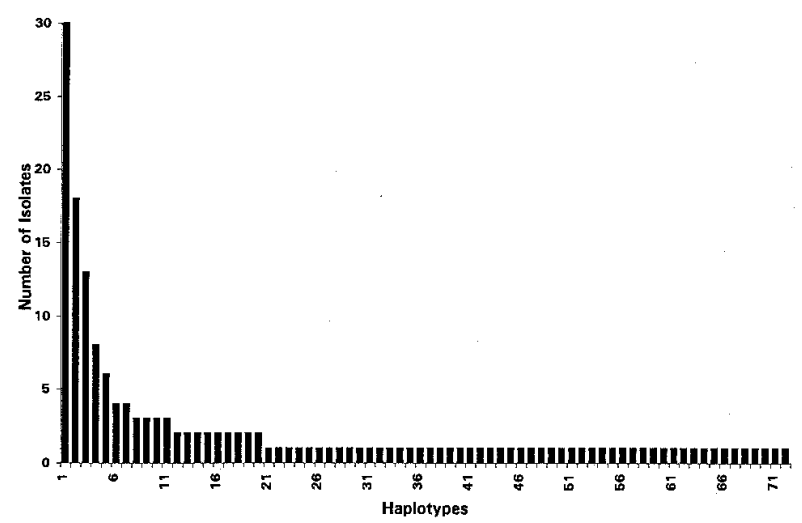

Fig. 1. Frequency distribution of restriction fragment length polymorphism haplotypes among the 165 isolates representing a worldwide collection of Fusarium oxysporum f. sp. cubense. 


\section{RESULTS}

In this study, 38 isolates of $F$. oxysporum $\mathrm{f}$. sp. cubense were screened for polymorphisms using 19 probe-enzyme combinations. Only six of the 19 probe-enzyme combinations were monomorphic among the 38 selected isolates, indicating a high degree of genetic diversity among the isolates. The entire collection of 165 isolates was then scored for polymorphisms using the 13 probeenzyme combinations that were found to be informative during the initial screening of isolates. A multilocus RFLP haplotype was assigned to each isolate based on the allelic data for all probeenzyme combinations. Only 72 distinct multilocus haplotypes were detected among the 165 isolates. The five most common haplotypes represented $45 \%$ of the isolates; 50 of the haplotypes were represented by a single isolate (Fig. 1). The median number of alleles per locus was three and, if three alleles were present at each locus, theoretically $1.16 \times 10^{9}\left(3^{19}\right)$ possible haplotypes could exist for this collection of $F$. oxysporum f. sp. cubense. However, the majority of single-isolate haplotypes found were the result of one to a few allelic differences from a more common haplotype.

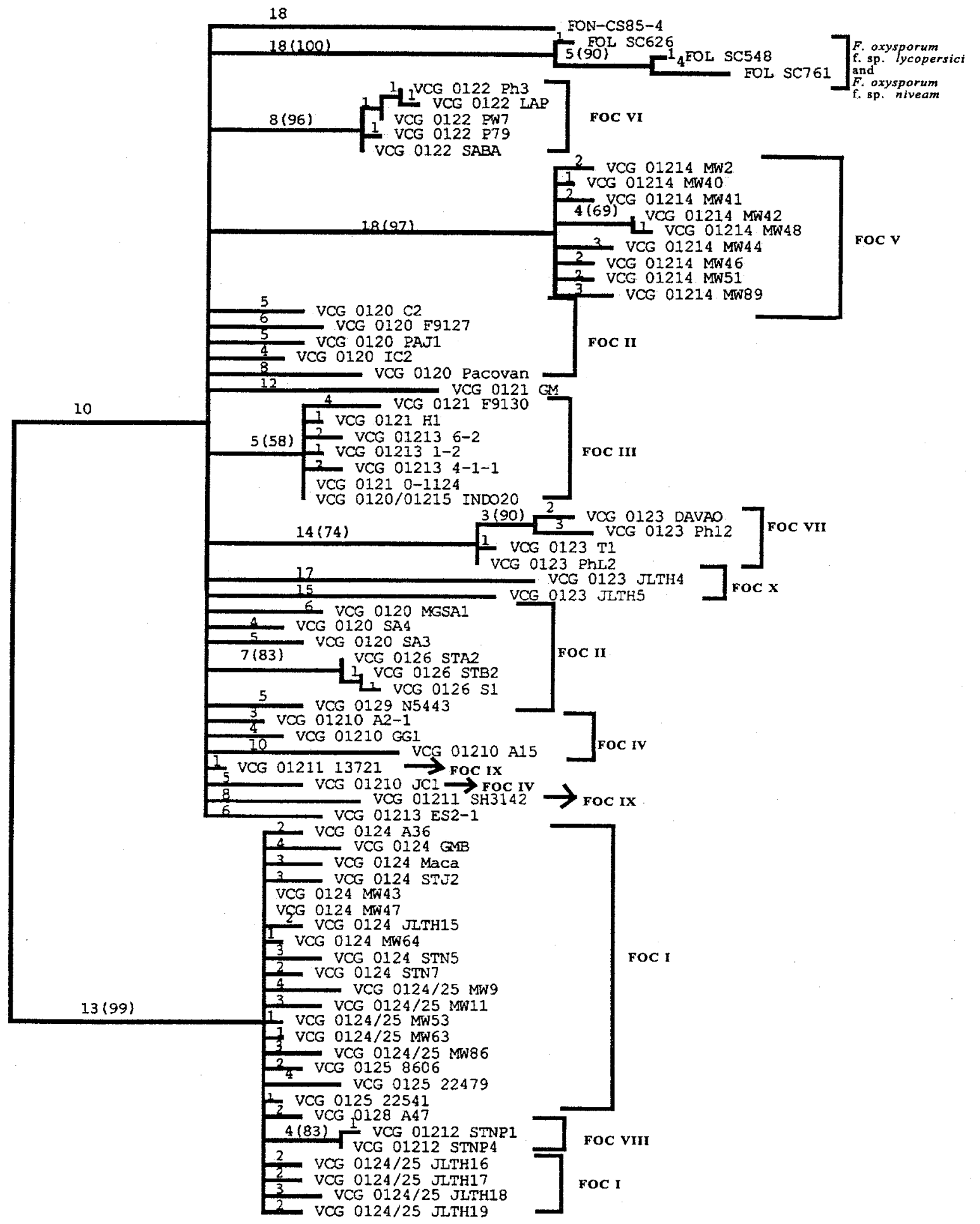

Fig. 2. Midpoint-rooted $50 \%$ majority rule consensus tree representing 500 bootstrap replicates. One isolate represents each of the 72 restriction fragment length polymorphism haplotypes of Fusarium oxysporum $\mathrm{f}$. sp. cubense, three isolates of $F$. oxysporum $\mathrm{f}$. sp. lycopersici, and one isolate of $F$. oxysporum $\mathrm{f}$. sp. niveum. Branch lengths are indicated on each branch, and bootstrap values are in parentheses. Tree length $=351$, consistency index $=0.214$, homoplasy index $=0.786$, retention index $=0.705$, and rescaled consistency index $=0.151$. 
To determine relatedness among isolates, the 72 RFLP haplotypes were subjected to phenetic and cladistic analyses. Both types of analyses produced trees with similar branching patterns. The $50 \%$ majority rule bootstrap consensus tree generated by PAUP 3.1.1 is presented in Figure 2. A dichotomy with strong bootstrap support (99\%) was observed on the midpoint-rooted tree among the 72 haplotypes representing the $165 F$. oxysporum f. sp. cubense isolates and four isolates from other formae speciales. Isolates of F. oxysporum f. sp. cubense belonging to VCGs 0124, 0124/0125, 0125 , 0128, and 01212 formed one main phylogenetic branch (99\% bootstrap support), while isolates belonging to VCGs 0120, 0121, 0122, 0123, 0126, 0129, 01210, 01211, 01213, 01214, $0120 / 01215$, and 01215 , as well as the isolates of $F$. oxysporum $\mathrm{f}$. sp. lycopersici and $F$. oxysporum $\mathrm{f}$. sp. niveum, were found on the second main branch.

Isolates composing these two branches could be further divided into eight major clades, which have moderate to strong bootstrap support (values greater than $70 \%$ ). Within one of the branches, isolates in VCGs 0124, 0124/0125, 0125, and 0128 formed one clade. Isolates in VCG 01212 were genetically similar but distinct (83\% bootstrap support) (described below) from these isolates. Within the second main branch (99\% bootstrap support), five clades were identified. Isolates in VCGs 0122 ( $96 \%$ bootstrap support), 0123 (74\% bootstrap support), 0126 ( $83 \%$ bootstrap support), 01214 (97\% bootstrap support), and isolates of $F$. oxysporum f. sp. lycopersici (100\% bootstrap support) each formed their own clade. Isolates in VCGs 0121, 01213, and three isolates in 0120/01215 formed a clade of weak support (58\%) and, therefore, could not be confidently differentiated from isolates in VCGs 0120, 0123 (two isolates), 0129, 01210, 01211, 0120/01215, and the single isolate of $F$. oxysporum $\mathrm{f}$. sp. niveum.

All clades with strong bootstrap support were composed of isolates that had identical or nearly identical multilocus haplotypes and are referred to here as clonal lineages. Additionally, many of the isolates that could not be resolved using bootstrap analysis shared nearly identical multilocus haplotypes with other isolates. To further understand the genetic relationships among unresolved isolates, we used a simple matching coefficient of similarity for comparison (Table 3). Isolates with coefficients of similarity ranging from 0.94 to 1.00 were considered to be within a clonal lineage. This range reflects apparent natural groups (Fig. 2); isolates within a lineage possess either small or no genetic differences. In cases in which isolates did not fall within this range for all pairwise comparisons, isolates were included in the lineage if they shared values near or within the specified range with the majority of isolates composing the lineage. These isolates are marked with a "y" in Table 1. Two isolates, ES2-1 and GM, could not be assigned to lineage based on these criteria.

A similarity matrix, which includes coefficients of similarity for selected isolates representing the major RFLP haplotypes and VCGs, is presented in Table 3 (a complete matrix is available from the corresponding author by request). In general, VCGs aligned with single clonal lineages; exceptions to this were isolates in VCG 0123. Table 4 lists each lineage (with the prefix FOC), the number of isolates represented, the VCG of each lineage, and its geographical distribution. Seventy-four percent of the isolates studied were represented by lineages FOC I, FOC II, and FOC III. Each of these three lineages contained more than one VCG, with lineages FOC I and FOC II having a pantropical distribution. Isolates in FOC IV through FOC $\mathrm{X}$ each belonged to a single VCG and represented one to a few geographical regions.

Coefficients of similarity between isolates of FOC I and FOC II ranged from 0.66 to 0.74 . By comparison, two isolates of $F$. oxysporum f. sp. lycopersici had coefficients of similarity ranging from 0.55 to 0.71 compared with isolates in FOC I and from 0.64 to 0.74 compared with isolates in FOC II. The single isolate of $F$. oxysporum $\mathrm{f}$. sp. niveum had coefficients of similarity ranging from 0.75 to 0.81 compared with isolates in FOC I and from 0.73 to 0.76 compared with isolates in FOC II. Thus, the two largest lineages of $F$. oxysporum f. sp. cubense each are more genetically similar to the $F$. oxysporum f. sp. niveum isolate than to each other. Similarly, they are roughly as genetically distinct from each other as either is to the F. oxysporum $\mathrm{f}$. sp. lycopersici isolates.

All isolates in VCG 01214 composed FOC V. Isolates in this lineage formed a clade exhibiting the longest branch length compared with all other clades representing $F$. oxysporum f. sp. cubense isolates. In fact, its length was comparable to the branch lengths of the clades containing the isolates from the other formae speciales (Fig. 2). Additionally, isolates composing this lineage had coefficients of similarity that did not align closely to any other

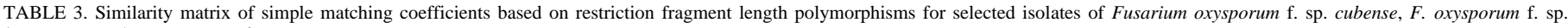
lycopersici, and F. oxysporum f. sp. niveum

F912 O IC2 F9130 H1 SABA DAVAO T1 $\quad$ Ph12 PhL2 JLTH4 MW43 MW64 MW11 8606 STA2 $\quad$ S1 N5443 A2-1 SH3142 STNP4 1 1-2 MW2 MW41 MW51 MW89 INDO20 SC626 SC761 CS85-4

VCG 0120 F9127

VCG 0120 IC2

VCG 0121 F9130

VCG $0121 \mathrm{H} 1$

VCG 0122 SABA

VCG 0123 DAVAO

VCG 0123 T1

VCG $0123 \mathrm{Ph} 12$

VCG 0123 PhL2

VCG 0123 JLTH 4

VCG 0124 MW43

VCG 0124 MW64

VCG 0124/0125 MW

VCG 01258606

VCG 0126 STA2

VCG 0126 S1

VCG 0129 N5443

VCG 01210 A2-1

VCG 01211 SH3142

VCG 01212 STNP4

VCG 01213 1-2

VCG 01214 MW2

VCG 01214 MW41

VCG 01214 MW51

VCG 01214 MW89

VCG 0120/01215 INDO20

SC626

SC761

CS85-4 1

0.98

$\begin{array}{lll}0.82 & 0.85 & 1\end{array}$

$\begin{array}{llll}0.86 & 0.88 & 0.96 & 1\end{array}$

$\begin{array}{llllll}0.91 & 0.88 & 0.82 & 0.86 & 1\end{array}$

$\begin{array}{lllllll}0.78 & 0.75 & 0.74 & 0.75 & 0.75 & 1\end{array}$

$\begin{array}{llllllll}0.8 & 0.78 & 0.74 & 0.78 & 0.78 & 0.93 & 1\end{array}$

$\begin{array}{llllllll}0.76 & 0.76 & 0.73 & 0.76 & 0.74 & 0.94 & 0.92 & 1\end{array}$

$\begin{array}{lllllllll}0.81 & 0.79 & 0.75 & 0.79 & 0.79 & 0.94 & 0.99 & 0.93 & 1\end{array}$

$\begin{array}{llllllllll}0.78 & 0.75 & 0.72 & 0.75 & 0.8 & 0.88 & 0.93 & 0.87 & 0.94\end{array}$

$\begin{array}{lllllllllll}0.73 & 0.71 & 0.62 & 0.66 & 0.75 & 0.74 & 0.79 & 0.73 & 0.8 & 0.81 & 1\end{array}$

$\begin{array}{llllllllllll}0.72 & 0.69 & 0.61 & 0.65 & 0.74 & 0.75 & 0.78 & 0.74 & 0.79 & 0.8 & 0.99 & 1\end{array}$

$\begin{array}{lllllllllllll}0.74 & 0.72 & 0.64 & 0.67 & 0.76 & 0.73 & 0.78 & 0.72 & 0.79 & 0.85 & 0.96 & 0.95 & 1\end{array}$

$\begin{array}{llllllllllllll}0.71 & 0.68 & 0.6 & 0.64 & 0.73 & 0.74 & 0.76 & 0.73 & 0.78 & 0.79 & 0.98 & 0.99 & 0.94\end{array}$

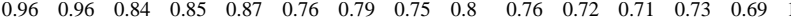

$\begin{array}{llllllllllllllll}0.94 & 0.94 & 0.81 & 0.82 & 0.85 & 0.74 & 0.79 & 0.75 & 0.8 & 0.76 & 0.72 & 0.71 & 0.73 & 0.69 & 0.98 & 1\end{array}$

$\begin{array}{llllllllllllllllll}0.96 & 0.99 & 0.86 & 0.87 & 0.87 & 0.74 & 0.76 & 0.75 & 0.78 & 0.74 & 0.69 & 0.68 & 0.71 & 0.67 & 0.95 & 0.93\end{array}$

$\begin{array}{lllllllllllllllll}0.89 & 0.92 & 0.91 & 0.92 & 0.87 & 0.81 & 0.84 & 0.82 & 0.85 & 0.81 & 0.72 & 0.71 & 0.73 & 0.69 & 0.93 & 0.91 & 0.91\end{array}$

$\begin{array}{lllllllllllllllllll}0.91 & 0.93 & 0.85 & 0.86 & 0.86 & 0.75 & 0.75 & 0.74 & 0.76 & 0.78 & 0.71 & 0.69 & 0.69 & 0.68 & 0.89 & 0.87 & 0.92 & 0.89 & 1\end{array}$

$\begin{array}{llllllllllllllllllll}0.73 & 0.71 & 0.6 & 0.64 & 0.75 & 0.72 & 0.76 & 0.71 & 0.78 & 0.79 & 0.95 & 0.94 & 0.92 & 0.93 & 0.72 & 0.72 & 0.69 & 0.69 & 0.71 & 1\end{array}$

$\begin{array}{lllllllllllllllllllll}0.86 & 0.88 & 0.94 & 0.98 & 0.84 & 0.75 & 0.8 & 0.79 & 0.81 & 0.78 & 0.68 & 0.67 & 0.69 & 0.66 & 0.85 & 0.85 & 0.87 & 0.92 & 0.86 & 0.66 & 1\end{array}$

$\begin{array}{llllllllllllllllllllllllllll}0.76 & 0.74 & 0.75 & 0.74 & 0.79 & 0.75 & 0.8 & 0.74 & 0.79 & 0.8 & 0.68 & 0.67 & 0.69 & 0.66 & 0.78 & 0.75 & 0.75 & 0.8 & 0.76 & 0.68 & 0.74 & 1\end{array}$

$\begin{array}{llllllllllllllllllllllll}0.76 & 0.74 & 0.78 & 0.74 & 0.79 & 0.78 & 0.8 & 0.74 & 0.79 & 0.8 & 0.68 & 0.67 & 0.69 & 0.66 & 0.78 & 0.75 & 0.75 & 0.8 & 0.79 & 0.71 & 0.74 & 0.95 & 1\end{array}$

$\begin{array}{llllllllllllllllllllllll}0.79 & 0.76 & 0.75 & 0.74 & 0.79 & 0.75 & 0.8 & 0.74 & 0.79 & 0.8 & 0.68 & 0.67 & 0.69 & 0.66 & 0.8 & 0.78 & 0.78 & 0.8 & 0.79 & 0.68 & 0.74 & 0.98 & 0.95 & 1\end{array}$

$\begin{array}{lllllllllllllllllllllllll}0.8 & 0.78 & 0.74 & 0.78 & 0.82 & 0.79 & 0.84 & 0.78 & 0.82 & 0.84 & 0.72 & 0.71 & 0.73 & 0.69 & 0.79 & 0.76 & 0.76 & 0.81 & 0.8 & 0.72 & 0.78 & 0.94 & 0.94 & 0.94 & 1\end{array}$

$\begin{array}{llllllllllllllllllllllllll}0.87 & 0.89 & 0.95 & 0.99 & 0.85 & 0.76 & 0.79 & 0.78 & 0.8 & 0.76 & 0.67 & 0.66 & 0.68 & 0.65 & 0.86 & 0.84 & 0.88 & 0.93 & 0.87 & 0.65 & 0.99 & 0.75 & 0.75 & 0.75 & 0.79 & 1\end{array}$

$\begin{array}{lllllllllllllllllllllllllllllllll}0.71 & 0.73 & 0.76 & 0.75 & 0.75 & 0.69 & 0.72 & 0.68 & 0.73 & 0.74 & 0.69 & 0.68 & 0.71 & 0.67 & 0.72 & 0.72 & 0.74 & 0.76 & 0.75 & 0.67 & 0.75 & 0.66 & 0.68 & 0.66 & 0.67 & 0.74 & 1\end{array}$

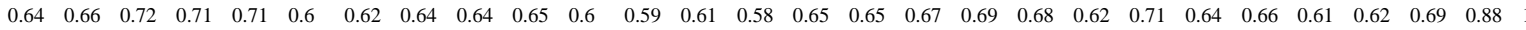

$\begin{array}{lllllllllllllllllllllllllllll}0.74 & 0.74 & 0.75 & 0.76 & 0.76 & 0.8 & 0.85 & 0.79 & 0.86 & 0.85 & 0.8 & 0.79 & 0.79 & 0.78 & 0.75 & 0.75 & 0.75 & 0.8 & 0.76 & 0.78 & 0.79 & 0.81 & 0.79 & 0.81 & 0.8 & 0.78 & 0.75 & 0.71 & 1\end{array}$ 
lineage. For example, isolates in FOC V had coefficients of similarity ranging from 0.62 to 0.73 compared with isolates in FOC I, from 0.72 to 0.81 compared with isolates in FOC II, and from 0.61 to 0.69 compared with the $F$. oxysporum f. sp. lycopersici isolates. This group had a large number of lineage-specific alleles at several RFLP loci, which accounted for its relative lack of similarity to other $F$. oxysporum f. sp. cubense isolates. All of the isolates in VCG 01214 have a very limited geographical distribution. Isolates in this group also do not form chlamydospores (R. C. Ploetz, unpublished data) as other $F$. oxysporum isolates do, which is usually a defining trait for the species.

FOC VII consisted of the majority of isolates in VCG 0123. FOC X consisted of two additional isolates in VCG 0123. Similar to FOC V, isolates composing these lineages had coefficients of similarity that did not align closely to any other lineage. Surprisingly, the RFLP multilocus haplotypes of isolates within these lineages consisted of alleles similar to those in both FOC I and FOC II, in addition to some lineage-specific alleles (Table 5). A representative FOC VII isolate (PhL2) shared 43\% (6/14) of polymorphic alleles with isolates in FOC II and 36\% (5/14) of these alleles with isolates in FOC I. By contrast, the isolates in FOC I displayed only $29 \%$ (4/14) allelic similarity with isolates in FOC II. With the exception of FOC V, isolates in the other lineages more closely aligned with isolates in either FOC I or FOC II. Unlike isolates in other lineages, the multilocus haplotype of isolates in FOC VII and FOC X appeared to represent a combination of alleles from FOC I and FOC II.

The mitochondrial DNA haplotypes of a subset of 55 isolates representing the major VCGs were examined to determine their genetic relationships based on an additional independent genetic marker. Isolates within the same VCG shared identical mitochondrial DNA haplotypes. Isolates could be divided into three major groups based on visual assessment of similar, though not identical, mitochondrial RFLP patterns. Isolates in VCGs 0123, 0124, $0124 / 0125,0125,0128,01212$, and 01214 formed one group. Isolates in VCGs 0120, 0121, 0122, 0129, 01213, 0120/01215, and 01215 formed a second group. Isolates in VCGs 0126 and 01210 formed a third group. In general, these groupings aligned with those based on RFLP analysis of single-copy loci, although more groups could be resolved using the latter method.

Measures of gametic disequilibrium were performed for alleles at nine loci (Table 6). Even though many of the individual comparisons were not significant, 34 of the 36 pairwise comparisons among alleles at different RFLP loci showed significant nonrandom associations at the $1 \%$ level. Many individual allele combi-

TABLE 4. Clonal lineages of Fusarium oxysporum f. sp. cubense isolates, their geographical distributions, and corresponding vegetative compatibility groups (VCGs)

\begin{tabular}{|c|c|c|c|}
\hline Lineage $^{z}$ & $\begin{array}{l}\text { No. of } \\
\text { isolates }\end{array}$ & Geographic distribution & VCG represented \\
\hline FOC I & 65 & $\begin{array}{l}\text { Australia, Brazil, Burundi, Comores } \\
\text { Islands, Honduras, Jamaica, Malawi, } \\
\text { Nicaragua, Tanzania, Thailand, } \\
\text { Uganda, and United States (Florida) }\end{array}$ & $\begin{array}{c}0124,0124 / 0125 \\
0125, \text { and } 0128\end{array}$ \\
\hline FOC II & 43 & $\begin{array}{l}\text { Australia, Brazil, Canary Islands, Costa } \\
\text { Rica, Honduras, Jamaica, Malaysia, } \\
\text { South Africa, and Taiwan }\end{array}$ & $\begin{array}{l}0120,0126,0129, \\
\text { and } 01215\end{array}$ \\
\hline FOC III & 15 & Indonesia and Taiwan & $\begin{array}{l}0121,01213, \text { and } \\
0120 / 01215\end{array}$ \\
\hline FOC IV & 11 & United States (Florida) & 01210 \\
\hline FOC V & 9 & Malawi & 01214 \\
\hline FOC VI & 8 & Philippines & 0122 \\
\hline FOC VII & 5 & Philippines and Taiwan & 0123 \\
\hline FOC VIII & 3 & Tanzania & 01212 \\
\hline FOC IX & 2 & Australia & 01211 \\
\hline FOC X & 2 & Thailand & 0123 \\
\hline
\end{tabular}

z Isolates ES2-1 in VCG 01213 and GM in VCG 0121 did not align with any lineage based on coefficient of similarity data. nations were not present in the population, but the chi-square test for these combinations was not significant; based on the overall allelic frequency, the expected number of these combinations was small. In contrast, for the most common alleles, the large number of nonrandom associations was indicated by significantly larger or smaller numbers of observations when compared with the expected frequency of these combinations.

\section{DISCUSSION}

Several lines of evidence support the concept that $F$. oxysporum f. sp. cubense has a clonal population structure in line with criteria established by Tibayrenc et al. (34). A unifying feature of clonally reproducing organisms is widespread geographic distribution of a few successful clones. Even though this study identified 72 multilocus haplotypes in a worldwide collection of $F$. oxysporum $\mathrm{f}$. sp. cubense, the five most common haplotypes accounted for nearly half of the isolates. Additionally, the two most common haplotypes were found on all five continents sampled in this study, indicating the pantropical distribution of a small number of genotypes.

Further evidence of clonal reproduction is the absence of recombinant genotypes. Significant gametic disequilibrium for alleles at 34 of 36 loci tested supported nonrandom association between alleles of different loci. In addition, the strong correlation between independent genetic markers (VCG, mitochondrial, and multilocus RFLP haplotype) also is indicative of a clonally reproducing organism (34).

This study confirms that, in phylogenetic analysis of $F$. $o x$ ysporum $\mathrm{f}$. sp. cubense using parsimony, VCG is a strong predictor of cladistic groupings. Further differentiation into lineages may be done based on coefficients of similarity of RFLP haplotypes. At least 21 VCGs have been described for $F$. oxysporum f. sp. $\mathrm{cu}$ bense (22-26), and representatives from 17 of these VCGs were included in this study. With the exception of the two isolates that could not be assigned to a lineage and two isolates in VCG 0123 , all isolates within a VCG were in the same clade and clonal lineage. The correlation between VCG and RFLP patterns has been observed previously in $F$. oxysporum formae speciales including albedinis, conglutinans, dianthi, gladioli, lycopersici, melonis, pisi, raphani, and vasinfectum (4,7-9,11,13,15,16,18,21,33,36).

Although VCGs are good indicators of genetic similarity among the individuals composing them, they do not provide information regarding the genetic similarity of individuals in different VCGs. In fact, this study shows that isolates belonging to different VCGs could have identical or nearly identical RFLP haplotypes. With two exceptions, the entire collection of isolates consisted of only 10 distinct clonal lineages (Table 4). Clonal lineages provide a conservative system for grouping similar isolates, and the coefficient of similarity provides a numerical value to assess genetic relationships among isolates representing different lineages. This is in contrast to VCG groupings in which, for an asexually reproducing organism such as $F$. oxysporum, it is impossible to determine the quantitative differences among individuals in different VCGs. We propose the use of clonal lineages, rather than VCG, to

TABLE 5. A comparison of allelic data for isolates in FOC I, FOC II, and FOC VII

\begin{tabular}{lc}
\hline Isolate $($ VCG) & Alleles $^{\mathrm{z}}$ \\
\hline A36 VCG 0124 & 11111111111111 \\
IC2 VCG 0120 & 22122122221222 \\
PhL2 VCG 0123 & 12132123331113 \\
\hline
\end{tabular}

y Isolates A36 and IC2 represent the two largest restriction fragment length polymorphism haplotypes in FOC I and FOC II, respectively, and PhL2 represents an isolate in FOC VII.

z Alleles found in the most common haplotypes were given the number 1 . Alleles in the second most common haplotype, if different from haplotype 1 , were given the number 2. Alleles in isolate PhL2, if different than those in the two most common haplotypes were given the number 3 . 
genetically characterize similar isolates of $F$. oxysporum $\mathrm{f}$. sp. cubense. In most instances, VCGs can be used to predict lineage.

Many of the isolates used in this study also have been classified based on their electrophoretic karyotype (3) and RAPD profile (2). Based on their electrophoretic karyotype, Boehm et al. (3) divided 110 isolates from 11 VCGs into two major groups. Group I contained isolates from VCGs 0124, 0124/0125, 0125, 01210, and 01214 and was characterized by high chromosome number and large relative genome size (39.9 to 58.9 megabase pairs [Mbp]). Group II contained isolates from VCGs 0120, 0121, 0122, 0123, 0129, and 01213 and had correspondingly fewer chromosomes and smaller genome sizes (32.1 to 44.9 Mbp). Using RAPD analysis, Bentley et al. (2) similarly found that 54 isolates, representing 11 VCGs, could be divided into two major groups. Group I contained isolates in VCGs 0120, 0121, 0122, 0126, 01210, 01211, and 01212, while group II contained isolates in VCGs 0123, 0124, 0124/0125, and 0125. Cluster analysis indicated that VCG 01212 was distinct from the other VCGs in group I, and 0123 was distinct from group II.

Although the results presented here corroborate most of the broad conclusions made previously, this study provides additional, and sometimes disparate, conclusions regarding the affinities of some of these isolates. The bootstrap 50\% majority rule consensus tree showed strong support for more than two clades among isolates of $F$. oxysporum f. sp. cubense. The midpoint-rooted tree divides isolates into two major groups. One group is composed of isolates in five VCGs, which represent two significant clades. Isolates in this major group are remarkably homogenous, and the branch lengths that separate isolates are minimal. In contrast, the second branch encompasses isolates representing eight lineages, 11 VCGs, a large number of significant clades, as well as isolates belonging to other formae speciales of $F$. oxysporum. Isolates representing the second group had more variable branch lengths compared with isolates in the first major branch.

With the exception of VCGs 0122, 0123, 0126, 01210, 01212, and 01214 , the phylogenetic relationship of isolates in 10 of the 17 VCGs corresponds to those defined by previous studies $(2,3)$. Unlike previous investigations, isolates in VCGs 0122, 0126, 01212, and 01214 each formed individual clades with bootstrap values greater than $70 \%$. Additionally, because this study used numerous independent clones, had a large sample size, and provided bootstrap support for the clades, it gives a greater resolution of the re- lationships among isolates of $F$. oxysporum $\mathrm{f}$. sp. cubense than do previous studies.

A number of the clonal lineages described here are phylogenetically distinct. Some isolates of $F$. oxysporum f. sp. cubense are as genetically dissimilar to one another as they are to other formae speciales of $F$. oxysporum (e.g., niveum and lycopersici). Similarly, Appel and Gordon (1) found that, based on analysis of mitochondrial DNA, isolates of $F$. oxysporum $\mathrm{f}$. sp. melonis in two different VCGs were more closely related to a nonpathogen VCG than to each other. One interpretation of these results for $F$. oxysporum $\mathrm{f}$. sp. cubense is that isolates belonging to the dissimilar groups acquired their ability to be pathogenic on banana independently.

FOC V contains isolates from the Misuku Hills in Malawi, a relatively small area (approximately 400 square kilometers) on the country's northern border with Tanzania (25). All isolates in FOC V are in VCG 01214, and this is one of the few VCGs that has not been found in Southeast Asia, the center of origin of banana. Due to numerous lineage-specific alleles, FOC V is distant from all other lineages. One hypothesis is that this lineage of $F$. oxysporum f. sp. cubense may have evolved in East Africa independently of other members of the taxon.

Alternatively, isolates within FOC $\mathrm{V}$ could have arisen by a founder effect. Bananas probably first arrived at the island of Madagascar in the later half of the first millennium A.D. and from there moved to the coastal and then interior regions of the African continent (28). Diverse genotypes of banana are now found in East Africa, many of which are found nowhere else. It is possible that the pathogen was moved from Southeast Asia on the bananas introduced to Africa and, as a result of geographic isolation or through adaptation to endemic bananas, isolates in VCG 01214 may have diverged from their Asian progenitors.

FOC VII and FOC X contain isolates in VCG 0123. The RFLP haplotype of isolates belonging to these groups carry an assortment of alleles from the two major lineages (FOC I and FOC II), as well as a number of lineage-specific alleles. Additionally, isolates composing this clade are quite heterogeneous; the five isolates composing FOC VII belong to two significant sister groups. Also, all of the isolates in VCG 0123 fall neither into the same lineage nor in a single clade. Based on this information, we hypothesize that this group may provide evidence of an ancient genetic exchange between individuals in FOC I and FOC II. Alter-

TABLE 6. Clone-corrected measurements of gametic disequilibrium among pairs of alleles in a worldwide collection of Fusarium oxysporum f. sp. cubense

\begin{tabular}{|c|c|c|c|c|c|c|c|c|}
\hline & \multicolumn{8}{|c|}{ Probe/enzyme combinations } \\
\hline & 120 Hae III & 162 DraI & 177 EcoRV & 187 EcoRV & 204 HaeIII & 228 EcoRV & 260 EcoRV & 261 EcoRV \\
\hline 7 DraI & $\begin{array}{l}13 / 35 \\
77.7(24)\end{array}$ & $\begin{array}{c}4 / 10 \\
25.1(5)\end{array}$ & $\begin{array}{c}4 / 18 \\
56.8(10)\end{array}$ & $\begin{array}{c}5 / 30 \\
174.4(20)\end{array}$ & $\begin{array}{c}5 / 15 \\
87.4(8)\end{array}$ & $\begin{array}{c}7 / 30 \\
50.0(24)\end{array}$ & $\begin{array}{c}5 / 20 \\
183.1(12)\end{array}$ & $\begin{array}{l}22 / 40 \\
86.6(28)\end{array}$ \\
\hline 120 HaeIII & & $\begin{array}{c}8 / 14 \\
31.33(6)\end{array}$ & $\begin{array}{l}17 / 21 \\
68.3(12)\end{array}$ & $\begin{array}{c}9 / 42 \\
122.6(30)\end{array}$ & $\begin{array}{c}11 / 21 \\
142.4(12)\end{array}$ & $\begin{array}{c}9 / 42 \\
121.1(30)\end{array}$ & $\begin{array}{l}13 / 28 \\
87.5(18)\end{array}$ & $\begin{array}{c}14 / 56 \\
184.3(42)\end{array}$ \\
\hline 162 DraI & & & $\begin{array}{l}4 / 6 \\
4.91(2)^{*}\end{array}$ & $\begin{array}{c}8 / 12 \\
37.7(5)\end{array}$ & $\begin{array}{l}4 / 6 \\
5.49(2)^{*}\end{array}$ & $\begin{array}{c}5 / 12 \\
128.7(5)\end{array}$ & $\begin{array}{c}5 / 8 \\
29.3(3)\end{array}$ & $\begin{array}{c}6 / 16 \\
23.3(7)\end{array}$ \\
\hline 177 EcoRV & & & & $\begin{array}{c}5 / 18 \\
33.0(10)\end{array}$ & $\begin{array}{c}4 / 9 \\
73.09(4)\end{array}$ & $\begin{array}{c}7 / 18 \\
78.1(10)\end{array}$ & $\begin{array}{c}2 / 12 \\
37.7(6)\end{array}$ & $\begin{array}{c}9 / 24 \\
54.6(14)\end{array}$ \\
\hline 187 EcoRV & & & & & $\begin{array}{c}6 / 18 \\
40.5(10)\end{array}$ & $\begin{array}{c}17 / 36 \\
126.2(25)\end{array}$ & $\begin{array}{l}6 / 24 \\
63.54(15)\end{array}$ & $\begin{array}{c}6 / 48 \\
65.2(35)\end{array}$ \\
\hline 204 HaeIII & & & & & & $\begin{array}{l}7 / 18 \\
51.3(10)\end{array}$ & $\begin{array}{c}6 / 12 \\
48.2(6)\end{array}$ & $\begin{array}{l}11 / 24 \\
85.8(14)\end{array}$ \\
\hline 228 EcoRV & & & & & & & $\begin{array}{c}8 / 24 \\
53.7(15)\end{array}$ & $\begin{array}{c}7 / 48 \\
57.2(35)\end{array}$ \\
\hline 260 EcoRV & & & & & & & & $\begin{array}{c}16 / 32 \\
190.6(21)\end{array}$ \\
\hline
\end{tabular}

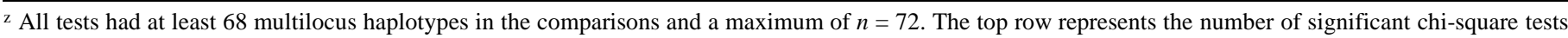
$(P<0.05)$ between individual alleles at different restriction fragment length polymorphism loci over the total number of tests made for each pairwise comparison. The bottom row represents the results of a chi-square test for the significance of association between all alleles at the two loci. The number in the parentheses is the degrees of freedom for the test. All are significant at $P<0.01$, except those noted with $*$, which are not significant at $P<0.05$. 
natively, it may represent an ancestral group possessing primitive character states found in FOC I and FOC II.

In conclusion, isolates of $F$. oxysporum $\mathrm{f}$. sp. cubense represent a genetically diverse group of organisms, many of which are distantly related. Previous studies on other formae speciales indicate that many are genetically diverse. However, to our knowledge, this study is the first to present evidence that a forma specialis of $F$. oxysporum may be polyphyletic. The implied independent origin of pathogenicity to banana in some of the lineages has practical implications for work on this disease. Much effort is devoted toward developing cultivars of banana that are resistant to Fusarium wilt. Clearly, new hybrids should be screened against isolates representing the two most common lineages of the pathogen (FOC I and FOC II). Ideally, breeding programs could screen new hybrids against isolates from each clonal lineage to increase the probability of developing cultivars resistant to genetically distinct populations of the pathogen.

\section{ACKNOWLEDGMENTS}

Research reported herein was supported, in part, under grants COM5600-G-00-0023-0 and HRN-5600-G-00-2031-00, Program in Science and Technology Cooperation, Office of the Science Advisor, U.S. Agency for International Development. Florida journal series R-05532. We thank T. Gordon, K. O'Donnell, and L. Rosewich for reviewing this manuscript and those who donated isolates listed in Table 1. We also thank B. Bowen for helpful comments and suggestions on data analysis, M. Bell for the genetic distance computer program, B. McDonald for the Excel spreadsheet with linkage disequilibrium formulas, and U. Benny for expert technical assistance.

\section{LITERATURE CITED}

1. Appel, D. J., and Gordon, T. R. 1994. Local and regional variation in populations of Fusarium oxysporum from agricultural field soils. Phytopathology 84:786-791.

2. Bentley, S., Pegg, K. G., and Dale, J. L. 1995. Genetic variation among a world-wide collection of isolates of Fusarium oxysporum f. sp. cubense analyzed by RAPD-PCR fingerprinting. Mycol. Res. 99:1378-1384.

3. Boehm, E. W. A., Ploetz, R. C., and Kistler, H. C. 1994. Statistical analysis of electrophoretic karyotype variation among vegetative compatibility groups of Fusarium oxysporum f. sp. cubense. Mol. Plant-Microbe Interact. 7:196-207.

4. Bosland, P. W., and Williams, P. H. 1987. An evaluation of Fusarium oxysporum from crucifers based on pathogenicity, isozyme polymorphism, vegetative compatibility and geographic origin. Can. J. Bot. 65: 2067-2073.

5. Brandes, E. W. 1919. Banana wilt. Phytopathology 9:339-390.

6. Correll, J. C., Klittich, C. J. R., and Leslie, J. F. 1987. Nitrate nonutilizing mutants of Fusarium oxysporum and their use in vegetative compatibility tests. Phytopathology 77:1640-1646.

7. Elias, K. S., and Schneider, R. W. 1991. Vegetative compatibility groups in Fusarium oxysporum f. sp. lycopersici. Phytopathology 81:159-162.

8. Elias, K. S., Zamir, D., Lichtman-Pleban, T., and Katan, T. 1993. Population structure of Fusarium oxysporum f. sp. lycopersici: Restriction fragment length polymorphisms provide genetic evidence that vegetative compatibility group is an indicator of evolutionary origin. Mol. PlantMicrobe Interact. 6:565-572.

9. Fernandez, D., Assigbetse, K. B., Dubois, M. P., and Geiger, J. P. 1994. Molecular characterization of races and vegetative compatibility groups in Fusarium oxysporum f. sp. vasinfectum. Appl. Environ. Microbiol. 60: 4039-4046.

10. Jacobson, D. J., and Gordon, T. R. 1991. Fusarium oxysporum f. sp. melonis: A case study of diversity within a forma specialis. Phytopathology 81:1064-1067.

11. Kim, D. H., Martyn, R. D., and Magill, C. W. 1992. Restriction fragment length polymorphism groups and physical map of mitochondrial DNA from Fusarium oxysporum f. sp. niveum. Phytopathology 82:346-353.

12. Kistler, H. C., Bosland, P. W., Benny, U., Leong, S., and Williams, P. H. 1987. Relatedness of strains of Fusarium oxysporum from crucifers measured by examination of mitochondrial and ribosomal DNA. Phytopathology 77:1289-1293.

13. Kistler, H. C., and Leong, S. A. 1986. Linear plasmidlike DNA in the plant pathogenic fungus Fusarium oxysporum f. sp. conglutinans. J. Bacteriol. 167:587-593.
14. Leslie, J. F. 1993. Vegetative compatibility in fungi. Annu. Rev. Phytopathol. 31:127-151.

15. Manicom, B. Q., and Baayen, R. P. 1993. Restriction fragment length polymorphisms in Fusarium oxysporum f. sp. dianthi and other fusaria from Dianthus species. Plant Pathol. 42:851-857.

16. Manicom, B. Q., Bar-Joseph, M., Kotze, J. M., and Becker, M. M. 1990. A restriction fragment length polymorphism probe relating vegetative compatibility groups and pathogenicity in Fusarium oxysporum f. sp. dianthi. Phytopathology 80:336-339.

17. McDonald, B. A., Miles, J., Nelson, L. R., and Pettway, R. E. 1994. Genetic variability in nuclear DNA in field populations of Stagonospora nodorum. Phytopathology 84:250-255.

18. Mes, J. J., van Doorn, J., Roebroeck, E. J. A., van Egmond, E., van Aartrijk, J., and Boonekamp, P. M. 1994. Restriction fragment length polymorphisms, races and vegetative compatibility groups within a worldwide collection of Fusarium oxysporum f. sp. gladioli. Plant Pathol. 43: 362-370.

19. Moore, N. Y., Hargreaves, P. A., Pegg, K. G., and Irwin, J. A. G. 1991. Characterization of strains of Fusarium oxysporum f. sp. cubense by production of volatiles. Aust. J. Bot. 39:161-166.

20. Moore, N. Y., Pegg, K. G., Langdon, P. W., Smith, M. K., and Whiley, A. W. 1993. Current research on Fusarium wilt of banana in Australia. Pages 270-284 in: Proc. Int. Symp. Recent Dev. Banana Cultivation Technol. R. V. Valmayor, S. C. Hwang, R. Ploetz, S. W. Lee, and V. N. Roa, eds. International Network for the Improvement of Banana and Plantain, Asia and Pacific Network, Los Baños, Laguna, Philippines.

21. Namiki, F., Shiomi, T., Kayamura, T., and Tsuge, T. 1994. Characterization of the formae speciales of Fusarium oxysporum causing wilts of cucurbits by DNA fingerprinting with nuclear repetitive DNA sequences. Appl. Environ. Microbiol. 60:2684-2691.

22. Ploetz, R. C. 1990. Population biology of Fusarium oxysporum f. sp. cubense. Pages 63-76 in: Fusarium Wilt of Banana. R. C. Ploetz, ed. The American Phytopathological Society, St. Paul, MN.

23. Ploetz, R. C. 1994. Panama disease: Return of the first banana menace. Int. J. Pest Manage. 40:326-336.

24. Ploetz, R. C., Braunworth, W. S., Jr., Hasty, S., Gantotti, B., Chizala, C. T., Banda, D. L. N., Makina, D. W., and Channer, A. G. 1992. Fusarium wilt of banana (Panama disease) in Malawi. Fruits 47:503-508.

25. Ploetz, R. C., and Correll, J. C. 1988. Vegetative compatibility among races of Fusarium oxysporum f. sp. cubense. Plant Dis. 72:325-328.

26. Ploetz, R. C., Vázquez, A., Nagel, J., Benscher, D., Sianglew, P., Srikul, S., Kooariyakul, S., Wattanachaiyingcharoen, W., Lertrat, P., and Wattanachaiyingcharoen, D. Current status of Panama disease in Thailand. Fruits. In press.

27. Sambrook, J., Fritsch, E. F., and Maniatis, T. 1989. Molecular Cloning: A Laboratory Manual. 2nd ed. Cold Spring Harbor Laboratory Press, Cold Spring Harbor, NY.

28. Simmonds, N. W. 1962. The Evolution of the Bananas. Longmans, Green and Co. Ltd., London.

29. Sneath, P. H., and Sokal, R. R. 1973. Numerical Taxonomy. W. H. Freeman \& Co., San Francisco.

30. Sorensen, S., Pegg, K. G., and Dale, J. L. 1993. RAPD-PCR analysis of genetic variation within Australian populations of Fusarium oxysporum $\mathrm{f}$. sp. cubense. Pages 285-295 in: Proc. Int. Symp. Recent Dev. Banana Cultivation Technol. R. V. Valmayor, S. C. Hwang, R. Ploetz, S. W. Lee, and V. N. Roa, eds. International Network for the Improvement of Banana and Plantain, Asia and Pacific Network, Los Baños, Laguna, Philippines.

31. Stover, R. H. 1959. Studies on Fusarium wilt of banana. IV. Clonal differentiation among wild type isolates of Fusarium oxysporum f. sp. cubense. Can. J. Bot. 37:245-255.

32. Swofford, D. L. 1993. PAUP: Phylogenetic analysis using parsimony. Version 3.1. Illinois Natural History Survey, Champaign, IL.

33. Tantaoui, A., Ouinten, M., Geiger, J.-P., and Fernandez, D. 1996. Characterization of a single clonal lineage of Fusarium oxysporum f. sp. albedinis causing Bayoud disease of date palm in Morocco. Phytopathology 86:787-792.

34. Tibayrenc, M., Kjellberg, F., and Ayala, F. J. 1990. A clonal theory of parasitic protozoa: The population structures of Entamoeba, Giardia, Leishmania, Naegleria, Plasmodium, Trichomonas and Trypanosoma and their medical and taxonomical consequences. Proc. Natl. Acad. Sci. 87:2414-2418.

35. Weir, B. S. 1990. Genetic data analysis: Methods for discrete population genetic data. Sinauer Associates, Sunderland, MA.

36. Whitehead, D. S., Coddington, A., and Lewis, B. G. 1992. Classification of races by DNA polymorphisms analysis and vegetative compatibility grouping in Fusarium oxysporum f. sp. pisi. Physiol. Mol. Plant Pathol. 41:295-305.

37. Wollenweber, H. W., and Reinking, O. A. 1935. Die Fusarien, ihre Beschreibung, Schadwirkung ung Bekampfung. Paul Parey, Berlin. 